\title{
Governance Mechanisms and Performance of Publicly Traded Companies
}

\author{
J. Augusto Felício ${ }^{1}$ \& María Purificación Galindo Villardón ${ }^{2}$ \\ ${ }^{1}$ ISEG - School of Economics and Management, University of Lisbon, Lisbon, Portugal \\ ${ }^{2}$ Statistics Department, University of Salamanca, Salamanc, Spain \\ Correspondence: J. Augusto Felício, ISEG-School of Economics and Management, Rua Miguel Lúpi, n. ${ }^{\circ}$ \\ 20-Gab. 603, 1200-725, Lisboa, Portugal. Tel: 351-213-970-264. E-mail: jaufeli@iseg.utl.pt
}

Received: February 8, 2014

Accepted: October 22, 2014

Online Published: November 22, 2014

doi:10.5539/ijbm.v9n12p1

URL: http://dx.doi.org/10.5539/ijbm.v9n12p1

\begin{abstract}
Rooted in agency theory, this study analyzes the relationship between governance mechanisms and the performance of listed firms in countries with different levels of economic development and shareholding concentration. The study uses graphic representations of the HJ-Biplot method to perform holistic analysis. This method is effective for qualitative evaluation of relationships. Based on observations from 146 listed companies, this study compares two different contexts and governance backgrounds. Results show that governance mechanisms affect firm performance differently depending on whether firms are operating in a context characterized by concentration or dispersion of voting rights. Sector and company size also influence corporate governance mechanisms and firm performance. This holistic approach yields important contributions to the literature because, despite the number of studies that exist, there is still insufficient understanding of how specific governance mechanisms affect company valuation and performance. This study demonstrates the importance and influences that sector of activity, company size, and context have in developing proper corporate governance mechanisms.
\end{abstract}

Keywords: corporate governance, governance mechanisms, agency theory, performance

\section{Introduction}

Governance mechanisms have become central to understanding organizational performance. They are especially important for shareholders (e.g., Daily, Dalton, \& Rajagopalan, 2003), and the choice of mechanism depends upon numerous factors (Larcker, Richardson, \& Tuna, 2007). Sometimes, however, firms adopt inadequate governance mechanisms due to i) lack of knowledge on the mechanisms' effects on performance and, ii) insufficient knowledge on the mechanisms combined effects.

Despite a large body of literature on the subject, there is a lack of consensus among researchers (e.g., Larcker et al., 2007) as to the effect of corporate governance on performance. This research addresses the lack of consistency among previous studies (Coles, McWilliams, \& Sen, 2001), namely incoherent, contradictory findings of relationships between governance and performance variables (Rhoades, Rechener, \& Sandaramurthy, 2000). The HJ-Biplot method (Gabriel, 1971) introduces graphic representation to the study of governance mechanisms, marking an innovation in this field. Using HJ-Biplot affords researchers a simultaneous integrated view of relationships and their implications (Gabriel, 1971; Galindo, 1986). The HJ-Biplot method consists of a joint representation (in a low-dimension vector space, usually a plane) of rows and columns of a matrix, X. The HJ-Biplot method uses markers (points/vectors) for rows and columns. Markers are obtained from the singular value decomposition (SVD) of the data matrix. The HJ-Biplot method permits a holistic treatment of factors and variables in complex environments such as contexts where organizations operate (Garcia-Sanchez, Frias-Aceituno, \& Rodriguez-Dominguez, 2013). Another reason for studying this set of variables is that governance mechanisms (Jobome, 2006) have different effects on company results and company value depending on the organizations' size, sector, and development level of the country where the company has its headquarters.

Agency theory supports the importance of incentives (Eisenhardt, 1989) and governance mechanisms (Shleifer \& Vishny, 1997) in aligning management and shareholder interests. Even now, corporate governance theory has 
yet to be unified (Brown, Beekes, \& Verhoeven, 2011).

The sample for this research consisted of observations from 146 companies listed on the London Stock Exchange (UK) and the Euronext Lisbon (Portugal). Data were for 2004, 2005, and 2006. The UK and Portugal provide good study contexts because they have different levels of economic development and differ in several other contextual dimensions.

This paper presents analysis of the relationship between governance mechanisms and the performance of listed firms in two countries with different degrees of economic development. Analysis was based on innovative graphic representation. The aim of this research was to answer the following questions: Do governance mechanisms influence firm performance? Does the influence of these mechanisms on firm performance differ according to level of economic development in the country where the firm has its headquarters? What are the implications of company size and sector? Can the interaction between all factors be observed simultaneously?

The main contribution of this research lies in its holistic, integrated view of the HJ-Biplot graphic representation model because of the great complexity of organizations and the importance of governance mechanisms. Another important finding is that governance mechanisms affect firm performance according to concentration of voting rights. Activity and company size also exert an influence on the relationship between governance mechanisms and performance.

Following the introduction, the second section presents the literature review and states the hypotheses. The third and fourth sections set forth the conceptual model, variables, and research methods, instruments and data. The fifth section presents the results, and the sixth section discusses these results. Finally, the seventh section presents conclusions, implications for management, limitations, and suggestions for further research.

\section{Literature Review and Hypothesis}

\subsection{Independence of Board Members}

According to Ghosh and Sirmans (2003), appointing independent board members is an important mechanism to reduce agency problems that adversely influence performance. Daily and Dalton (2003) argued that "more independent boards will result in greater oversight of corporate management and that this, in turn, will lead to improved firm performance." $\mathrm{Li}$ (1994) claimed that the corporate board offers a potentially effective governance tool because of its combination of independence, legal power, and expertise. Among the authors to have found a positive influence on performance, Geddes and Vinod (1997) reported that companies with weak performance that appointed more independent board members boosted company results.

Hutchinson (2002) found that having a high proportion of independent board members in high-growth companies is associated with better performance in terms of return on equity (ROE). Uzun, Szewczyk, and Varma (2004) reported that having a larger proportion of external and independent board members is associated with a lower probability of making decisions that could harm company growth. Hermalin and Weisbach (2003) claimed that, although independent board members are generally believed to provide more effective control of a company, there is little evidence that independent board members are associated with better company performance. This lack of evidence is due to the board's endogenous nature (Coles, Naveen, \& Naveen, 2006), and the need for information as well as oversight. Thus, we test the following hypothesis in relation to board composition:

Hypothesis 1: The percentage of independent members on the board of directors is positively related to corporate performance.

\subsection{Management Incentives}

According to agency theory, the main purpose of various governance mechanisms is to align agents' personal interests with principals' interests to ensure the company performs well (Daily et al., 2003; Dalton, Daily, Certo, \& Roengpitya, 2003; Eisenhardt, 1989). One such control mechanism is the use of financial incentives, namely compensation or sanction (e.g., Beatty \& Zajac, 1994; Houmes \& Skantz, 2010). These forms of performance-based compensation help to align agents' interests with those of owners and shareholders, at least partially (Jiang, Petroni, \& Wang, 2010; McDonald, Khanna, \& Westphal, 2008).

Managers may receive compensation in a number of ways: meeting fees, stock awards, or options. The causal relationship between payments to managers and company performance nonetheless remains unclear, with some authors reporting a relationship (Boyd, 1994; Cordeiro, Veliyath, \& Eramus, 2000) and others finding no link (Hempel \& Fay, 1994; Vafeas, 1999). Kubo (2005) noted a scarcity of studies that analyze effects of managers' performance-based pay on company results, and confirmed a weak relationship in a study of large Japanese 
companies. Mishra and Nielsen (2000) verified that performance-based pay should serve as an alternative to independent board members because it aligns shareholder interest with management incentives. They emphasized a trade-off between relying on independent board members to increase performance and ensuring alignment of interests.

Cordeiro et al. (2000) verified that business performance positively correlates with management compensation, and observed that company growth relates to the amount of compensation used to motivate managers to expend the extra effort needed to grow a business. We therefore test the following hypothesis related to management incentives:

Hypothesis 2: Adopting performance-based incentives positively influences corporate performance.

\subsection{Concentration of Voting Rights}

Some studies (Lins, 2003; Suto, 2003) have reported that concentration of ownership or voting rights is positively associated with firm performance, and the concentration of ownership is especially relevant in countries where investor protection is low (often less developed economies) because concentration of ownership mitigates conflict between owners and management. Gillan and Starks (2003) pointed out that the "magnitude and nature of agency problems are directly related to ownership structures", which vary between countries. For example, Kapopoulos and Lazaretou (2007) studied Greek firms, and found that greater concentration of ownership led to a positive effect on performance. Kuznetsov, Kapelyushnikov, and Dyomina (2008) observed that ownership concentration may negatively affect firm performance. Nevertheless, they also reported that, in certain institutional environments, a coalition of several significant owners might have a favorable impact on firm performance. Tam and Tan (2007), however, argued that concentration of voting rights and control systems drive managers to entrenchment and lead them to dominate or control shareholder interests. The hypothesis to test, therefore, is the following:

Hypothesis 3: Concentration of shareholder voting rights positively influences corporate performance.

\subsection{Company Characteristics}

Tam and Tan (2007) found that company characteristics such as size and sector were related to performance. In the USA, Anderson and Reeb (2003) found that company size was negatively related to company valuation. Company characteristics are determined by the type of business, investment, and control strategies adopted by shareholders and the board of directors. These company characteristics are also driven by the existence of shareholders with a greater propensity to invest in companies in specific sectors. Thus, we test the following hypothesis concerning company size and sector:

Hypothesis 4: Context affects how company size and sector influence corporate governance mechanisms and performance.

\subsection{Governance Mechanisms and Context}

Factors such as the architecture underpinning governance models are relevant. They are especially important to protect shareholder interests, which often differ from management interests. The separation of ownership and control, an idea associated with agency theory dating back to the 1970s, is a key issue in corporate governance (Learmount, 2002; Shleifer \& Vishny, 1997). Various authors (Bhojraj \& Sengupta, 2003; Wood \& Patrick, 2003) have found that adopting certain governance mechanisms helps to mitigate agency conflict. Armour, Deakin, and Knozelmann (2003), and Jobome (2006) advocated simultaneous use of different mechanisms, namely supervision through non-executive directors and executive remuneration agreements. Liu (2005) found evidence that, for companies in the UK, shareholder dispersion permits the market, rather than the company's largest shareholders, to influence corporate governance.

Countries' economic development undoubtedly influences society's structure and organization. Therefore, we expect to observe differences between governance models of companies in developed countries and those of companies in less developed countries, hence the final hypothesis:

Hypothesis 5: Context affects how governance mechanisms influence corporate performance.

\section{The Conceptual Model}

\subsection{Research Model}

The research model was based on evaluating the relationship between corporate governance mechanisms and corporate performance. We also analyzed control variables association and influence in the model for companies in less-developed and developed economies. Control variables were firm size (Cho \& Kim, 2007) and sector 
(Tam \& Tan, 2007).

\subsection{Variables and Definitions}

\subsubsection{Independent Variables}

We chose three variables to capture key concepts: percentage of independent directors on the board of directors (PID), variable remuneration of managers (VRM), and concentration of voting rights (CVR). Numerous authors have already applied these variables in prior studies (e.g., Brown et al., 2011).

Independent board members impartially evaluate top managers' activity, enrich the board with added experience, and help to raise the quality of the board of directors (Bhojraj \& Sengupta, 2003; Wood \& Patrick, 2003). We calculated the percentage of independent directors on the board of directors (PID) using information from company reports.

The variable remuneration of managers (VRM) was calculated using publicly disclosed information about executive board members' annual remuneration. According to several authors, a good (performance-dependent) remuneration plan contributes to aligning managers' interests with those of shareholders, minimizing the agency problem (Becht, Bolton, \& Roell, 2003).

The concentration of voting rights (CVR) refers to information concerning the three principal shareholdings and their voting rights. Some theorists have posited that association of corporate governance to a high capital dispersion pattern (i.e., a high number of shareholders) leads to there being no shareholders in a dominant position over any other (La Porta, Lopez, Shleifer, \& Vishny, 2000). Thus, "semi-concentrated property" (Becht et al., 2003) would solve collective action and agency problems, as several authors have concluded (Guriev \& Rachinsky, 2005; Pivovarsk, 2003).

\subsubsection{Dependent Variables}

Four dependent variables measured corporate performance: return on equity (ROE), Tobin's q ratio (Q), market-to-book ratio (MBR), and sales growth rate (SGR). These performance variables supported the study's goals.

Return on equity (ROE) equals net income (NI) divided by equity (E). This ratio is the principal efficiency metric for shareholders and investors, and measures how efficiently corporations use their equity (Brealey \& Myers, 2000). Brown and Caylor (2004) developed an index, and asserted that firms with weaker corporate governance were less profitable because they had lower return on assets, lower return on average equity, lower return on equity, and lower return on investment than did firms with stronger governance.

Tobin's q ratio $(\mathrm{Q})$ is based on the market, and expresses investors' valuation of the company. Many studies have employed this variable (Bhagat \& Black, 2002; Demsetz \& Villalonga, 2001). La Porta, Lopez, and Shleifer (2002) used an alternative calculation method for Tobin's q to study the relation between protection of investors and valuation of corporations. This was the chosen method in this research. Tobin's q is, therefore, equal to the book value of assets less book value of common equity less deferred taxes plus market value of common equity divided by the book value of assets.

The market-to-book ratio (MBR) compares the market value of shares with their book value. The MBR yields an index of value created for shareholders related to total investment by shareholders in the company.

The sales growth rate (SGR) checks operational performance of corporations (Gompers, Ishii, \& Metrick, 2003). This variable avoids repercussions of profit volatility and manipulability in relation to profit growth. The ratio establishes the relation between the current year's sales and sales of the previous year.

\section{Research Methods}

\subsection{Statistical Methodology}

To analyze relationships between governance mechanisms and firm performance, we organized the data into a $146 \times 7$ matrix. Each row represented a firm, and each column a variable: four corporate performance variables (ROE, Q, MBR, and SGR) and three corporate governance variables, over the 3 years (2004, 2005 and 2006). Data were standardized by columns.

Formal statistical testing (regression models, time series, etc.) is the classical method to analyze this type of data, but is not always the best approach. A disadvantage of such formal statistical methods is that the data must meet certain assumptions. In practice, however, these assumptions are seldom met. Exploratory multivariate data analysis methods offer a good alternative. A particularly interesting descriptive multivariate technique is the HJ-Biplot (Galindo, 1985, 1986; Galindo \& Cuadras, 1986), an extension of Gabriel's (1971) classical Biplots. 
Garcia-Sánchez (2013) used Biplots, especially HJ-Biplots. MULTBiplot software produced the calculations and graphs shown in this work (Vicente-Villardón, 2009).

\subsection{Data Collection/Sample}

The reports and accounts and the report on corporate governance of 46 corporations listed on Euronext Lisbon on December 31, 2004, 2005, and 2006 were obtained from the Portuguese Stock Market Supervisory Authority (CMVM). As of October 31, 20061294 companies were listed on the London Stock Exchange (LSE). From these, we randomly selected 100 companies with headquarters in the UK to form an initial sample. We maintained proportional distribution in the sample in terms of sector. The reports and accounts for these companies came from company sources. The fiscal year of sample companies varied, but an attempt was made to coincide with the Portuguese sample for 2004, 2005, and 2006. The overall sample thus comprised 146 firms, 46 of which were Portuguese and 100 of which were British. During the analysis, we dropped five UK companies because of missing values.

To establish differences between the UK and Portugal, we examined GDP (gross domestic product) per capita (purchasing power parity, ppp) in both countries. Portugal, with 10.6 million inhabitants had a 2007 GDP per capita of 76.2 (UE27 average $=100)$. In the UK (60.8 million inhabitants), 2007 GDP per capita was 119.2.

\section{Results}

\subsection{Descriptive Analysis}

Portuguese-listed firms were, on average, twice the size (in terms of sales) of British firms, had 11 times the amount of assets, had more than double the equity, and recorded slightly less than three times greater profit levels. These differences arose for two reasons. First, the Portuguese sample corresponded to all firms listed on the stock exchange, including the largest Portuguese companies. In addition, the Portuguese stock market is less mature than its British counterpart is.

Descriptive data analysis indicated that, on average, most British firms had independent directors, and almost twice the independent directors that Portuguese companies had. Moreover, Portuguese companies used variable compensation more than their British counterparts did. Finally, the level of capital dispersion was quite different in the two markets. British companies were generally considered widely held, whereas the shareholders of Portuguese firms mostly owned block-holdings.

\subsection{Multivariate Analysis}

The results of the HJ-Biplot, applied to the data matrix, confirmed inertia absorption of more than $48 \%$ of the total dispersion in three dimensions, and more than $38 \%$ of the factorial plane in two dimensions. These scores are acceptable, taking into account the nature of the data and the dimensions of the matrix (Table 1).

Table 1. Eigenvalues and variance explained (Inertia Absorption) for the HJ-Biplot of the matrix of all companies, excluding outliers

\begin{tabular}{cccc}
\hline Axis & Eigenvalue & Expl. Var. & Cumulative \\
\hline Axis 1 & 26.744 & 25.364 & 25.364 \\
Axis 2 & 18.978 & 12.772 & 38.136 \\
Axis 3 & 17.267 & 10.573 & 48.709
\end{tabular}

Note. Transformation of the raw data: column standardization;

Type of Biplot: HJ - Biplot (Baricentric Scaling).

The HJ-Biplot results show a negative correlation between independent directors (PID) and performance-based pay (VRM). The almost flat angle between PID and VRM reflects this correlation (Figure 1). PID, VRM, market-to-book ratio (MBR), and CVR (concentration of voting rights) correlate positively every year. PID and VRM share a low correlation with MBR, Tobin's q, ROE, and CVR. In Figure 1, the orthogonal or near orthogonal angles show these relations. PID, VRM, MBR, and Tobin's Q demonstrate good variability, reflected by the longitude of the vectors, which corresponds to good variance on the factorial axis. 


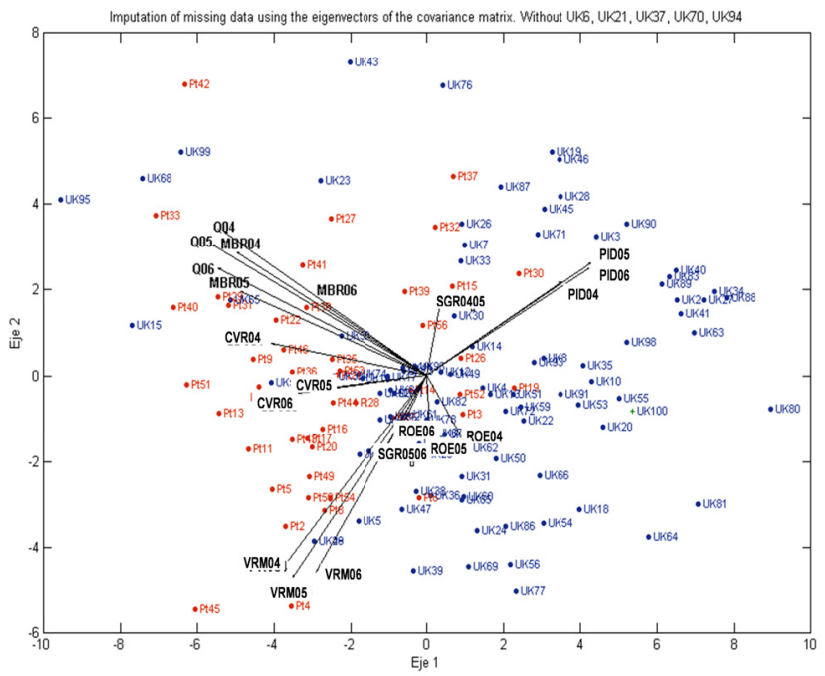

Figure 1. HJ-Biplot representation of the matrix of companies, excluding outliers

The HJ-Biplot representation clearly distinguishes British from Portuguese firms. A notable number of British companies share a similar profile, and form clusters. Clustering also occurs among Portuguese firms. The factorial plane demonstrates the existence of relationships among groups of elements (companies) and different factors (variables). Representation of sales growth (SGR), return on equity (ROE), and concentration of voting rights (CVR), is low or very low, contrary to the representation of other factors.

Tobin's $\mathrm{q}$ is the most important variable in the classification shown by the factorial plane in all years analyzed (Table 2). Over the three years, Tobin's q contributes most to axis 1 . The next biggest contributor is market-to-book ratio (MBR), especially in 2004 and 2005. Independent directors (PID) is the next most important, especially in 2005 and 2006. PID is the most relevant variable to axis 3. Performance-based pay (VRM), in all three years, is the most important variable to axis 2. Concentration of voting rights (CVR) is poorly represented in the factorial plane defined by axis 1 and axis 2 . The variables ROE04, ROE05, ROE06, SGR04_05, and SGR05_06 are irrelevant in the first 3 axes.

Table 2. Relative contributions of the polarization factors (variables) for all companies, excluding outliers

\begin{tabular}{cccc}
\hline Variables & Axis 1 & Axis 2 & Axis 3 \\
\hline PID04 & 231 & 90 & 377 \\
PID05 & 344 & 131 & 440 \\
PID06 & 335 & 117 & 423 \\
VRM04 & 248 & 352 & 199 \\
VRM05 & 232 & 418 & 215 \\
VRM06 & 159 & 393 & 192 \\
CVR04 & 311 & 10 & 74 \\
CVR05 & 167 & 2 & 82 \\
CVR06 & 266 & 4 & 3 \\
ROE04 & 16 & 41 & 14 \\
ROE05 & 0 & 50 & 0 \\
ROE06 & 9 & 31 & 1 \\
Q04 & 524 & 212 & 32 \\
Q05 & 589 & 176 & 11 \\
Q06 & 559 & 118 & 9 \\
MBR04 & 464 & 157 & 15 \\
MBR05 & 445 & 73 & 20 \\
MBR06 & 143 & 54 & 8 \\
SGR04_05 & 2 & 52 & 0 \\
SGR05_06 & 28 & 72 & 0 \\
\hline
\end{tabular}


Results of Portuguese and British companies' contributions to the model shows a good or acceptable level of explanatory power, considering the factorial planes made up of axes 1, 2, and 3 (Table 3).

Table 3. Relative contributions of all companies (elements), excluding outliers

\begin{tabular}{|c|c|c|c|c|c|c|c|c|c|}
\hline Row & Axis 1 & Axis 2 & Axis 3 & Sector & Row & Axis 1 & Axis 2 & Axis 3 & Sector \\
\hline Pt2 & 360 & 324 & 142 & Financials & UK28 & 258 & 377 & 176 & Financials \\
\hline Pt3 & 16 & 15 & 739 & Financials & UK29 & 124 & 210 & 287 & Financials \\
\hline Pt4 & 151 & 347 & 105 & Financials & UK30 & 27 & 105 & 4 & Technology \\
\hline Pt5 & 393 & 168 & 16 & Financials & UK31 & 96 & 654 & 5 & Industrials \\
\hline Pt6 & 2 & 374 & 22 & Financials & UK32 & 155 & 0 & 77 & Consumer services \\
\hline $\mathrm{Pt} 8$ & 201 & 274 & 61 & Financials & UK33 & 53 & 488 & 8 & Consumer goods \\
\hline Pt9 & 464 & 3 & 358 & Industrials & UK34 & 793 & 54 & 75 & Financials \\
\hline Pt11 & 609 & 82 & 180 & Industrials & UK35 & 496 & 2 & 24 & Financials \\
\hline Pt13 & 568 & 15 & 138 & Consumer services & UK36 & 0 & 313 & 20 & Consumer services \\
\hline Pt14 & 7 & 4 & 216 & Basic materials & UK38 & 5 & $\mathbf{5 5 7}$ & 298 & Consumer goods \\
\hline Pt15 & 12 & 118 & 316 & Technology & UK39 & 4 & 691 & 68 & Financials \\
\hline Pt16 & 169 & 34 & 423 & Consumer goods & UK40 & 679 & 98 & 41 & Financials \\
\hline Pt17 & 481 & 103 & 55 & Utilities & UK41 & 675 & 32 & 58 & Financials \\
\hline Pt19 & 115 & 2 & 514 & Financials & UK42 & 99 & 99 & 13 & Industrials \\
\hline Pt20 & 258 & 79 & 6 & Consumer services & UK43 & 6 & 84 & 3 & Consumer services \\
\hline Pt21 & 168 & 0 & 94 & Financials & UK44 & 122 & 13 & 160 & Consumer services \\
\hline Pt22 & 115 & 12 & 71 & Basic materials & UK45 & 303 & 488 & 16 & Financials \\
\hline Pt26 & 21 & 5 & 659 & Industrials & UK46 & 194 & 417 & 140 & Financials \\
\hline Pt27 & 193 & 409 & 233 & Consumer services & UK47 & 12 & 287 & 64 & Utilities \\
\hline Pt28 & 52 & 6 & 385 & Industrials & UK48 & 124 & 210 & 287 & Financials \\
\hline Pt29 & 571 & 65 & 6 & Consumer services & UK49 & 1 & 0 & 24 & Industrials \\
\hline Pt30 & 218 & 218 & 12 & Basic materials & UK50 & 350 & 404 & 1 & Basic materials \\
\hline Pt31 & 573 & 57 & 32 & Consumer services & UK51 & 558 & 22 & 156 & Utilities \\
\hline $\mathrm{Pt} 32$ & 1 & 221 & 11 & Industrials & UK52 & 38 & 321 & 409 & Industrials \\
\hline Pt33 & 563 & 158 & 3 & Consumer services & UK53 & 689 & 21 & 20 & Financials \\
\hline Pt35 & 374 & 9 & 0 & Industrials & UK54 & 167 & 215 & 391 & Preference \\
\hline Pt36 & 411 & 0 & 254 & Technology & UK55 & 806 & 9 & 12 & Financials \\
\hline Pt37 & 11 & 488 & 26 & Basic materials & UK56 & 147 & 600 & 15 & Financials \\
\hline Pt38 & 255 & 65 & 124 & Technology & UK57 & 233 & 0 & 176 & Financials \\
\hline Pt39 & 14 & 161 & 125 & Basic materials & UK58 & 384 & 64 & 209 & Industrials \\
\hline Pt40 & 511 & 30 & 70 & Telecommunications & UK59 & 282 & 24 & 1 & Consumer services \\
\hline Pt41 & 97 & 61 & 53 & Consumer services & UK60 & 66 & 553 & 84 & Financials \\
\hline $\mathrm{Pt} 42$ & 205 & 237 & 30 & Technology & UK61 & 73 & 278 & 73 & Debentures and loans \\
\hline Pt43 & 338 & 61 & 4 & Consumer services & UK62 & 116 & 284 & 51 & Financials \\
\hline Pt44 & 151 & 10 & 696 & Industrials & UK63 & 911 & 19 & 0 & Financials \\
\hline Pt45 & 387 & 314 & 6 & Industrials & UK64 & 623 & 264 & 1 & Preference \\
\hline Pt46 & 427 & 11 & 336 & Industrials & UK65 & 588 & 70 & 131 & Technology \\
\hline Pt47 & 477 & 2 & 190 & Industrials & UK66 & 398 & 248 & 37 & Financials \\
\hline Pt49 & 481 & 281 & 24 & Consumer services & UK67 & 3 & 162 & 5 & Financials \\
\hline Pt50 & 325 & 277 & 23 & Industrials & UK68 & 526 & 201 & 66 & Industrials \\
\hline Pt51 & 657 & 1 & 0 & Telecommunications & UK69 & 36 & 624 & 202 & Consumer goods \\
\hline Pt52 & 13 & 3 & 656 & Consumer services & UK71 & 320 & 421 & 39 & Financials \\
\hline Pt53 & 106 & 0 & 353 & Consumer goods & UK72 & 360 & 60 & 0 & Oil and Gas \\
\hline Pt54 & 199 & 253 & 60 & Industrials & UK73 & 3 & 0 & 86 & Financials \\
\hline Pt55 & 19 & 23 & 832 & Industrials & UK74 & 202 & 0 & 94 & Industrials \\
\hline Pt56 & 0 & 42 & 638 & Consumer goods & UK75 & 58 & 43 & 8 & Industrials \\
\hline UK1 & 105 & 112 & 363 & Financials & UK76 & 1 & 158 & 3 & Financials \\
\hline UK2 & 719 & 53 & 6 & Financials & UK77 & 68 & 320 & 20 & Financials \\
\hline UK3 & 426 & 228 & 140 & Financials & UK78 & 0 & 626 & 192 & Consumer goods \\
\hline UK4 & 137 & 5 & 232 & Debentures and loans & UK79 & 5 & 316 & 28 & Industrials \\
\hline
\end{tabular}




\begin{tabular}{|c|c|c|c|c|c|c|c|c|c|}
\hline UK5 & 81 & 281 & 432 & Basic materials & UK80 & 889 & 7 & 0 & Debentures and loans \\
\hline UK7 & 27 & 250 & 22 & Financials & UK81 & 737 & 133 & 0 & Preference \\
\hline UK8 & 213 & 4 & 4 & Industrials & UK82 & 1 & 5 & 2 & Technology \\
\hline UK9 & 141 & 194 & 226 & Technology & UK83 & 729 & 97 & 81 & Financials \\
\hline UK10 & 518 & 0 & 311 & Financials & UK84 & 84 & 11 & 411 & Industrials \\
\hline UK11 & 27 & 6 & 3 & Financials & UK85 & 28 & 285 & 5 & Financials \\
\hline UK12 & 66 & 4 & 8 & Industrials & UK86 & 119 & 357 & 216 & Financials \\
\hline UK13 & 410 & 27 & 116 & Preference & UK87 & 76 & 398 & 223 & Financials \\
\hline UK14 & 249 & 80 & 45 & Industrials & UK88 & 829 & 45 & 67 & Financials \\
\hline UK15 & 286 & 7 & 151 & Consumer services & UK89 & 677 & 83 & 69 & Financials \\
\hline UK16 & 295 & 0 & 23 & Consumer services & UK90 & 560 & 257 & 118 & Financials \\
\hline UK17 & 79 & 0 & 167 & Telecommunications & UK91 & 548 & 9 & 129 & Technology \\
\hline UK18 & 352 & 218 & 45 & Financials & UK92 & 55 & 6 & 120 & Consumer services \\
\hline UK19 & 26 & 65 & 0 & Financials & UK93 & 266 & 3 & 493 & Financials \\
\hline UK20 & 440 & 31 & 26 & Financials & UK95 & 644 & 120 & 16 & Technology \\
\hline UK22 & 316 & 56 & 18 & Debentures and loans & UK96 & 9 & 5 & 552 & Consumer services \\
\hline UK23 & 184 & 490 & 40 & Healthcare & UK97 & 116 & 366 & 187 & Industrials \\
\hline UK24 & 65 & 504 & 302 & Debentures and loans & UK98 & 739 & 17 & 87 & Financials \\
\hline UK25 & 2 & 564 & 26 & Financials & UK99 & 407 & 269 & 29 & Consumer services \\
\hline UK26 & 23 & 359 & 105 & Financials & UK100 & 480 & 12 & 194 & Consumer goods \\
\hline UK27 & 799 & 48 & 89 & Financials & & & & & \\
\hline
\end{tabular}

Analysis of the HJ-Biplot data matrix representation of complete data, excluding or including outliers, yielded similar results. Results were consistent, and justified more than $57 \%$ of dispersion in the maximum inertia space and more than $44 \%$ in the first factorial plane (Table 4 ).

Table 4. Eigenvalues and variance explained (Inertia Absorption) for the HJ-Biplot of the complete data matrix, excluding outliers

\begin{tabular}{cccc}
\hline Axis & Eigenvalue & Expl. Var. & Cumulative \\
\hline Axis 1 & 18.936 & 27.582 & 27.582 \\
Axis 2 & 14.684 & 16.586 & 44.168 \\
Axis 3 & 13.064 & 13.128 & 57.296 \\
\hline
\end{tabular}

Note. Transformation of the raw data: column standardization;

Type of Biplot: HJ- Biplot (Baricentric Scaling).

Considering the performance variables, the factorial plane illustrates how Tobin's q data for all years correlates strongly. The factorial plane also depicts a high level of correlation between market-to-book ratio (MBR) values in all three years, and a high correlation between Tobin's q and MBR in and between all years. All these variables have a high variance. Since these variables appear to the left of the plane and have low values in the axis, however, they are unimportant to classify firms. Conversely, variables that appear on the right have high values in the axis. Return on equity (ROE) correlates weakly over the three years and has a weak variance. SGR (sales growth) demonstrates a weak negative correlation and a very weak variance.

Corporate governance variables on the factorial plane-independent directors (PID), performance-based pay (VRM), and concentration of voting rights (CVR) - correlate strongly between each other and between years. PID and VRM have a strong variance on the plane, and correlate negatively in all years. The almost flat angle between PID and VRM reflects this result. CVR had low variance, and was is independent of governance variables with low variance.

Tobin's q, market-to-book ratio (MBR), performance-based pay (VRM), and independent directors (PID) form near right angles between each other, which shows they are almost completely independent of each other. Although concentration of voting rights (CVR) has a weak variance, it correlates strongly with Tobin's q and MBR. CVR was independent of the sales growth (SGR) variables, a relationship that the near right angles between them imply, although they had weak or very weak variance.

Portuguese firms tend toward the left side of the factorial image, whereas British firms tend to appear to the right. 
Upon further analysis, Portuguese firms appear to form two clusters: an industrial and technological cluster and a financial cluster. The industrial and technological cluster has a strong contribution to axis 1 , and is located to the left on the factorial plane. Its position therefore implies low values for Tobin's q and market-to-book ratio (MBR). Firms in this cluster are Pt29, Pt31, Pt33, Pt40, Pt41, Pt47, and Pt51. The financial cluster contributes strongly to axis 1 and axis 2. Companies have low performance-based pay (VRM) values. Companies that form this cluster are Pt2, Pt4, Pt5, Pt6, and Pt16.

British firms clearly form separate financial clusters. Large, medium-sized, and small firms form these clusters, with a strong contribution to axis 1 . Clusters appear on the right side of the factorial plane, meaning they have high values for PID (independent directors). The cluster consisting of firms UK2, UK27, UK34, UK40, UK41, UK63, UK83, UK88, and UK89 is noteworthy because of its extreme position on the gradient.

The HJ-Biplot illustrates how PID (independent directors) contributes high values to the factorial plane. The further to the right these values lie, the larger their contribution. Orthogonally projecting firms on the vectors that represent the variables yielded estimates of values for each firm, for each variable, for each year. The other two performance variables, sales growth (SGR) and return on equity (ROE), are poorly represented on the plane. They vary little or not at all, and thus yield little information.

British firms in the financial, industrial, technology, and health sectors are well represented on the factorial plane. They are concentrated on the right side of the HJ-Biplot, whereas Portuguese firms in the financial, industrial, technology, and service sectors appear on the left side, and are poorly represented on the factorial plane formed by axes 1 and 2. There is a clear predominance of British financial service firms, because they appear on the right, whereas British industrial, technology, and consumer service companies lie in the center of the factorial plane. Portuguese firms in the financial, industrial, and technology sectors appear on the left side of the image. Industrial and technology sectors dominate. The British consumer and service sectors, along with other sectors not listed, are generally weakly represented in the factorial plane, and are located in the bottom center of the Biplot.

\section{Discussion}

\subsection{Independence of Board Members and Performance}

Having independent directors (PID) contributes significantly to the factorial plane (axis 1), but does not influence company valuation either in terms of market-to-book ratio (MBR) or Tobin's q. Orthogonal relationships hold for vectors between these variables in all years.

The literature presents diverse findings regarding the influence of independent board members on performance. Finkelstein and D'Aveni (1994), and Peng, Buck, and Filatotchev (2003) have reported a positive relationship between company value and companies' having a board composed of independent directors. Bhagat and Black (1999) contradicted this finding, claiming that having such a board negatively influences performance. Barnhart and Rosenstein (1998) affirmed a curvilinear negative relationship, whereas Dalton et al. (1998), and Weir and Laing (1999) found no relationship at all between board composition and performance.

This study found a weak negative relationship between board composition (higher independence) and sales growth (SGR04_05). Furthermore, we observed no relation at all between board composition and company valuation or return on equity. This finding supports previous studies, indicating there may be a non-linear relationship between board composition and performance.

Large Portuguese industrial and technology companies do not rely on independent board members. Indeed, the projection of firms in the PID (independent directors) vectors is closely linked to shareholder dispersion. Large and medium-sized British firms are neutral in relation to PID (independent directors).

Among British financial companies, small enterprises predominated in the sample. Nonetheless, large, medium-sized, and small British financial companies have a strong positive relationship with board composition (PID). These firms also rely on financial incentives to compensate their management. The positive relationship with PID is an indication that they prefer to choose independent directors for board positions. Some large and medium-sized British financial companies distinguish according to their valuation (i.e., Tobin's $\mathrm{q}$ and market-to-book ratio). The opposite is true of industrial and technology companies. Some of these companies distinguish according to their valuation (i.e., Tobin's q and market-to-book ratio), which implies that management and shareholders collaborate closely. They probably do so because of innovation and market challenges.

Despite obvious differences between small and large British financial companies, both invest efforts in achieving an appropriate board composition. Companies from both groups prefer independent members. This preference 
differs from that of large industrial and technology companies, which are neutral toward, or even oppose, independent board members. Companies from service, consumer, and other sectors are neutral toward appointing independent board members.

In summary, British companies tend to appoint a higher proportion of independent board members than do Portuguese firms. Our results imply a weak negative influence of board composition on company performance, with a notable distinction between British and Portuguese companies, thus supporting hypothesis 1 . In addition to differences in board composition between companies in developed and less-developed economies, we observed several implications regarding performance.

\subsection{Management Incentives and Performance}

VRM (performance-based pay) has high values on the factorial plane (axis 2) in all years. These high values nonetheless do not demonstrate an influence on firm value (MBR, Q). This lack of influence is recognizable in the orthogonal vectors in the HJ-Biplot. VRM correlates with sales growth (SGR) from 2005 to 2006, although SGR has weak variance.

Previous studies are inconclusive in showing the influence of management pay incentives on firm performance. Some studies have found a relationship (Cordeiro et al., 2000; Dalton et al., 2003; Ryan \& Wiggins, 2004), whereas others have not (Kubo, 2005; Vafeas, 1999). As in other variables, previous research results seem contradictory. This study verified the existence of a weak positive relationship between management incentives and performance, measured by sales growth.

Unlike large British financial firms, small and medium-sized British financial firms tend not to use management pay incentives to improve company performance. The factorial plane and axis 2 illustrate this difference between SMEs and large firms, with a location of the firms on the right side of the graphic, opposite to the orientation of the VRM (performance-based pay) vector. Industrial and technology companies, and companies in other sectors (including consumer and service) use either few or no management pay incentives. Their location in the center of Figure 1 reflects this tendency.

Portuguese companies use management pay incentives with weak positive effects on sales growth. Figure 1 provides graphic evidence of this relationship: note the position of Portuguese companies on the left portion of the factorial plane and negative values along axis 2 . We accept research hypothesis 2 . When companies use management pay incentives, we observe a positive influence on performance. Context tends to determine whether companies use management pay incentives.

\subsection{Concentration of Voting Rights and Performance}

The concentration of voting rights (CVR) has weak variance on the first factorial plane (axes 1 and 2). CVR data for any year also correlates with CVR data from other years. In this plane of the HJ-Biplot representation, CVR correlates positively with market-to-book ratio (MBR) and Tobin's q, which measure firm performance. CVR is independent of the ROE and sales growth variables, and CVR has low variance.

Whether in the industrial/technology cluster or the service, consumer, and other firms cluster, the concentration of voting rights (CVR) in Portuguese companies is high, although with weak variance. This higher concentration of voting rights lets shareholders exert greater control over business activity, which may lead to problems in the form of minority shareholder expropriation.

British financial firms on the other hand, whether small, medium-sized, or large, tend to have dispersed voting rights, which gives management greater control and power to run these companies. A significant number of British industrial, technology, and other non-financial firms did not increase voting rights concentration, whereas a smaller number had a weak tendency toward concentration, and a some opted strongly for concentrated ownership.

Portuguese companies, in general, have a tendency toward concentration of voting rights, more or less as strongly as British companies' tendency toward dispersion. In both cases, some companies are indifferent. These companies lie at the junction of axes on the factorial plane. These findings highlight the importance of the agency theory.

The findings show that Portuguese companies tend to opt to concentrate voting rights, and that this choice positively affects performance. British companies, in contrast, opt for dispersion of voting rights, with negative effects on performance. These findings support hypothesis 3. The literature highlights the positive effect of concentration of voting rights on performance (e.g., Kapopoulos \& Lazaretou, 2007; Lins, 2003) and the negative effect of dispersion of voting rights on performance (Kuznetsov et al., 2008). In reference to 
concentration of voting rights, Tam and Tan (2007) emphasized the concentration and dispersion of voting rights importance in the context of agency conflict.

Results clearly show differences in concentration of firms' voting rights depending on the development level of their home economy. In less-developed economies, shareholders exert greater control. Conversely, in developed economies, there is a tendency for dispersion of voting rights, leading to more agency-related problems. These findings are consistent with existing literature.

Theory confirms these differences based on the dispersion or concentration of voting rights. Companies in less-developed economies are generally characterized by a greater concentration of voting rights. This high concentration of voting rights is especially relevant in countries where investor protection is weak.

\subsection{Company Characteristics and Performance}

Results reveal differences between companies in different sectors-financial, industry and technology, and other services - and of different sizes and the existence of implications on performance. The existence of implications on performance is also verified with regard to different contexts (i.e., Portugal and the UK), in line with Anderson and Reeb (2003), and Tam and Tan (2007), hence supporting hypothesis 4.

British financial companies—small, medium-sized, and large - clearly opt for independent directors. This negatively affects sales growth. British financial companies do not opt for performance-based financial incentives, which are positively related with sales growth.

Portuguese companies from the industry and technology, and financial sectors avoid independent directors and prefer performance-based financial incentives to boost sales growth. A tendency toward concentration of voting rights shows positive impacts on corporate valuation.

In summary, British firms, most notably financial companies, operate with dispersed shareholder capital structures, prefer independent board members, and give little importance to management incentives. Large Portuguese firms from industry, technology, finance, and non-financial services show an obvious proclivity for high voting rights concentration and management incentives, and generally do not choose independent board members.

\subsection{Governance Mechanisms and Contexts}

The factorial plane of the HJ-Biplot representation shows that companies from the UK differ from Portuguese firms in their use of governance mechanisms (Kapapoulos \& Lazaretus, 2007), influencing firms' performance, thus confirming hypothesis 5 .

The presence of independent boards of directors negatively influences the activity growth. Conversely, implementing performance-based financial incentives positively influences activity growth. Neither of these internal control mechanisms relates to ROE and corporate valuation ( $\mathrm{Q}$ and market-to-book value). A higher concentration of voting rights positively influences corporate valuation, but does not influence ROE or sales growth.

\section{Conclusions}

This innovative study used the HJ-Biplot, a graphic representation tool, to analyze a set of variables simultaneously and seamlessly. In addition to directly assessing relationships between variables in the model for Portuguese and UK companies, this approach simultaneously evaluated the effect of company size, business activity, and context. Results show that governance mechanisms influence firm performance. Furthermore, firms listed in the UK - a developed economy - use different mechanisms from those used by companies listed in Portugal — a less-developed economy.

Companies listed in the UK are characterized by having dispersed voting rights, whereas those listed in Portugal tend to have concentrated voting rights. Companies that carefully select the composition of their board of directors and that implement management incentives achieve weak positive or negative effects on sales. Companies that tend toward a concentration of voting rights show higher valuation.

The effect of governance mechanisms on performance depends on country, company size, and sector. British financial companies can be split into two groups: small and medium-sized companies, and large companies. Despite their differences, however, companies from both groups have dispersion of shareholders, independent board members, and limited use of performance-based pay incentives. In general, Portuguese companies offer incentives to management, and do not opt for independent board members. 


\subsection{Implications for Management}

This research demonstrates the importance and influence of context, sector, and company size on corporate governance mechanisms and performance. Use of the HJ-Biplot graphic representation is innovative in this research field. This method offers clear advantages in qualitative corporate governance studies because of its holistic analysis of multiple relationships.

\subsection{Limitations}

The Portuguese companies under study consisted of all companies listed on the Portuguese stock exchange. Almost all were large companies. This is a limitation of the current research because the sample size was limited. The limited sample size also prevented autonomous analysis of each sample.

The independence variable may be affected by the specific regulations in each country, and the range of interpretations of these regulations that each company may make.

\subsection{Directions for Future Research}

A need for further study arises from a lack of sufficient evidence on how company size and sector influence the relationship between governance and performance variables. It is also necessary to deepen our understanding of how governance mechanisms may influence performance differently in other contexts. Existing evidence fails to provide solid conclusions about how company size or sector influence company profitability, valuation, or growth.

\section{References}

Anderson, R., \& Reeb, D. (2003). Founding-family ownership and firm performance: Evidence from the S\&P 500. The Journal of Finance, 58, 1301-1328. http://dx.doi.org/10.1111/1540-6261.00567

Armour, J., Deakin, S., \& Konzelmann, S. (2003). Shareholder primacy and the trajectory of UK corporate governance. Cambridge: University of Cambridge.

Barnhart, S., \& Rosenstein, S. (1998). Board composition, managerial ownership and firm performance: An empirical analysis. The Financial Review, 33(4), 1-16. http://dx.doi.org/10.1111/j.1540-6288.1998.tb01393.x

Beatty, R., \& Zajac, E. (1994). Managerial incentives, monitoring, and risk bearing: A study of executive compensation, ownership, and board structure initial public offering. Administrative Science Quarterly, 39, 313-335. http://dx.doi.org/10.2307/2393238

Becht, M., Bolton, P., \& Roell, A. (2003). Corporate governance and control. In G. Costantinidis, M. Harris, \& R. Stulz (Eds.), Handbook of the economics of finance (pp. 1-109). Amsterdam: Elsevier Science B. V.

Bhagat, S., \& Black, B. (1999). The uncertain relationship between board composition and firm performance. Business Lawyer, 54, 921-963.

Bhagat, S., \& Black, B. (2002). The non-correlation between board independence and long-term firm performance. Journal of Corporation Law, 27(2), 231-273.

Bhojraj, S., \& Sengupta, P. (2003). Effect of corporate governance on bond ratings and yields: The role of institutional investors and outside directors. Journal of Business, 76(3), 455-475. http://dx.doi.org/10.1086/344114

Boyd, B. (1994). Board control and CEO compensation. Strategic Management Journal, 15(5), 335-344. http://dx.doi.org/10.1002/smj.4250150502

Brealey, R., \& Myers, S. (2000). Principles of corporate finance (6th ed.). Burr Ridge, IL: Irwin McGraw-Hill.

Brown, L., \& Caylor, M. (2004). Corporate governance and firm performance. Working Paper, Georgia: Georgia State University.

Brown, P., Beekes, W., \& Verhoeven, P. (2011). Corporate governance, accounting and finance: A review. Accounting and Finance, 51, 96-172. http://dx.doi.org/10.1111/j.1467-629X.2010.00385.x

Cho, D. S., \& Kim, J. (2007). Outside directors, ownership structure and firm profitability in Korea. Corporate Governance: An International Review, 15(2), 239-250. http://dx.doi.org/10.1111/j.1467-8683.2007.00557.x

Coles, J., McWilliams, V., \& Sen, N. (2001). An examination of the relationship of governance mechanisms to performance. Journal of Management, 27(1), 23-55. http://dx.doi.org/10.1177/014920630102700102

Coles, J., Naveen, D., \& Naveen, L. (2006). Managerial incentives and risk-taking. Journal of Financial 
Economics, 79, 431-468. http://dx.doi.org/10.1016/j.jfineco.2004.09.004

Cordeiro, J., Veliyath, R., \& Eramus, E. (2000). An empirical investigation of the determinants of outside director compensation. Corporate Governance: An International Review, 8(3), 268-279. http://dx.doi.org/10.1111/1467-8683.00204

Daily, C., \& Dalton, D. (2003). Dollars and sense: The path to board independence. The Journal of Business Strategy, 24(3), 41-43. http://dx.doi.org/10.1108/02756660310735027

Daily, C., Dalton, D., \& Rajagopalan, N. (2003). Governance through ownership: Centuries of practice, decades of research. Academy of Management Journal, 46, 151-158. http://dx.doi.org/10.2307/30040611

Dalton, D., Daily, C., Certo, S., \& Roengpitya, R. (2003). Meta-analyses of financial performance and equity: Fusion or confusion? Academy of Management Journal, 46, 13-26. http://dx.doi.org/10.2307/30040673

Dalton, D., Daily, C., Ellstrand, A., \& Johnson, J. (1998). Meta-analytic reviews of board composition, leadership structure, and financial performance. Strategic Management Journal, 19, 269-290. http://dx.doi.org/10.1002/(SICI)1097-0266(199803)19:3<269::AID-SMJ950>3.0.CO;2-K

Demsetz, H., \& Villalonga, B. (2001). Ownership structure and corporate performance. Journal of Corporate Finance, 7, 209-233. http://dx.doi.org/10.1016/S0929-1199(01)00020-7

Eisenhardt, K. (1989). Agency theory: An assessment and review. Academy of Management Review, 14, 57-74.

Finkelstein, S., \& D'Aveni, R. A. (1994). CEO duality as a double-edged sword: How boards of directors balance entrenchment avoidance and unity of command. Academy of Management Journal, 37, 1079-1108. http://dx.doi.org/10.2307/256667

Gabriel, K. R. (1971). The Biplot graphic display of matrices with application to principal component analysis. Biometrika, 58(3), 453-467. http://dx.doi.org/10.1093/biomet/58.3.453

Galindo, M. P. (1985). Contribuciones a la representación simultánea de datos multidimensionales. Tesis Doctoral, Spain: Universidad de Salamanca.

Galindo, M. P. (1986). Una alternativa de representación simultánea: HJ-Biplot. Questíio, 10(1), 13-23.

Galindo, M. P., \& Cuadras, C. M. (1986). Una extensión del método Biplot y su relación con otras técnicas. Public. de Bioestadistica y Biomatemática, 17. Spain: Univ. de Barcelona.

Garcia-Sánchez, I. M., Frias-Aceituno, J. V., \& Rodriguez-Dominguez, L. (2013). Determinants of corporate social disclosure in Spanish local governments. Journal of Cleaner Production, 39, 60-72. http://dx.doi.org/10.1016/j.jclepro.2012.08.037

Geddes, R., \& Vinod, H. (1997). CEO age and outside directors: A hazard analysis. Review of Industrial Organization, 12, 767-780. http://dx.doi.org/10.1023/A:1007752812928

Ghosh, C., \& Sirmans, C. F. (2003). Board independence, ownership structure and performance: Evidence from real estate investment trusts. Journal of Real Estate Finance and Economics, 26(2/3), 287-318. http://dx.doi.org/10.1023/A:1022932326610

Gillan, S. L., \& Starks, L. T. (2003). Corporate governance, corporate ownership and the role of institutional investors: A global perspective. Journal of Applied Finance, 12(2), 4-22.

Gompers, P., Ishii, J., \& Metrick, A. (2003). Corporate governance and equity prices. Quarterly Journal of Economics, 118, 107-155. http://dx.doi.org/10.1162/00335530360535162

Guriev, S., \& Rachinsky, A. (2005). The role of oligarchs in Russian capitalism. Journal of Economic Perspectives, 19(1), 131-150. http://dx.doi.org/10.1257/0895330053147994

Hempel, P., \& Fay, C. (1994). Outside director compensation and firm performance. Human Resource Management, 33(1), 111-133. http://dx.doi.org/10.1002/hrm.3930330107

Hermalin, B., \& Weisbach, M. (2003). Boards of directors as an endogenously determined institution: A survey of the economic literature. Economic Policy Review, 9, 7-26.

Houmes, R. \& Skantz, T. (2010). Highly valued equity and discretionary accruals. Journal of Business Finance and Accounting, 37, 60-92. http://dx.doi.org/10.1111/j.1468-5957.2009.02179.x

Hutchinson, M. (2002). An analysis of the association between firms' investment opportunities, board composition and firm performance. Asia-Pacific Journal of Accounting and Economics, 9, 17-38. http://dx.doi.org/10.1080/16081625.2002.10510598 
Jiang, J., Petroni, K., \& Wang, I. (2010). CFOs and CEOs: Who have the most influence on earnings management? Journal of Financial Economics, 96, 513-526. $\mathrm{http}: / / \mathrm{dx}$. doi.org/10.1016/j.jfineco.2010.02.007

Jobome, G. (2006). Management pay, governance and performance: The case of large UK nonprofits. Financial Accountability and Management, 22(4), 331-358. http://dx.doi.org/10.1111/j.1468-0408.2006.00429.x

Kapopoulos, P., \& Lazaretou, S. (2007). Corporate ownership structure and firm performance: Evidence from Greek firms. Corporate Governance: An International Review, 15(2), 144-158. http://dx.doi.org/10.1111/j.1467-8683.2007.00551.x

Kubo, K. (2005). Executive compensation policy and company performance in Japan. Corporate Governance: An International Review, 13(3), 429-436. http://dx.doi.org/10.1111/j.1467-8683.2005.00437.x

Kuznetsov, A., Kapelyushnikov, R., \& Dyomina, N. (2008). Performance of closely held firms in Russia: evidence from firm-level data. The European Journal of Finance, 14(4), 337-358. http://dx.doi.org/10.1080/13518470802041924

La Porta, R., Lopez, F., \& Shleifer, A. (2002). Government ownership of banks. Journal of Finance, 57, 265-301. http://dx.doi.org/10.1111/1540-6261.00422

La Porta, R., Lopez, F., Shleifer, A., \& Vishny, R. (2000). Investor protection and corporate governance. Journal of Financial Economics, 58, 3-27. http://dx.doi.org/10.1016/S0304-405X(00)00065-9

Larcker, D., Richardson, S., \& Tuna, I. (2007). Corporate governance, accounting outcomes, and organizational performance. The Accounting Review, 82, 963-1008. http://dx.doi.org/10.2308/accr.2007.82.4.963

Learmount, S. (2002). Theorizing corporate governance: New organizational alternatives. Cambridge: University of Cambridge.

Li, J. (1994). Ownership structure and board composition: A multi-country test of agency theory predictions. Managerial and Decision Economics, 15(4), 359-368. http://dx.doi.org/10.1002/mde.4090150409

Lins, K. (2003). Equity ownership and firm value in emerging markets. Journal of Financial and Quantitative Analysis, 38, 159-184. http://dx.doi.org/10.2307/4126768

Liu, G. (2005). Comparative corporate governance: The experience between China and the UK. Corporate Governance: An International Review, 13(1), 1-4. http://dx.doi.org/10.1111/j.1467-8683.2005.00397.x

McDonald, M., Khanna, P., \& Westphal, J. (2008). Getting them to think outside the circle: Corporate governance, CEOs' external advice networks, and firm performance. Academy of Management Journal, 51(3), 453-475. http://dx.doi.org/10.5465/AMJ.2008.32625969

Mishra, C., \& Nielsen, J. (2000). Board independence and compensation policies in large bank holding companies. Financial Management, 29(3), 51-70. http://dx.doi.org/10.2307/3666229

Peng, M. W., Buck, T., \& Filatotchev, I. (2003). Do outside directors and new managers help improve firm performance? An exploratory study in Russian privatization. Journal of World Business, 38, 348-360. http://dx.doi.org/10.1016/j.jwb.2003.08.020

Pivovarsky, A. (2003). Ownership concentration and performance in Ukraine's privatized enterprises. IMF Staff Papers, 50(1), 10-42.

Rhoades, D., Rechener, P., \& Sandaramurthy, C. (2000). Board composition and financial performance: A meta-analysis of the influence of outside directors. Journal of Management Issues, 12, 76-91.

Ryan, H., \& Wiggins, R. (2004). Who is in whose pocket? Director compensation, board independence, and barriers to effective monitoring. Journal of Financial Economics, 73, 497-524. http://dx.doi.org/10.1016/j.jfineco.2003.11.002

Shleifer, A., \& Vishny, R. (1997). A survey of corporate governance. The Journal of Finance, 2(2), 737-783. http://dx.doi.org/10.1111/j.1540-6261.1997.tb04820.x

Suto, M. (2003). Capital structure and investment behaviour of Malaysian firms in the 1990s: A study of corporate governance before the crisis. Corporate Governance: An International Review, 11(1), 25-39. http://dx.doi.org/10.1111/1467-8683.00299

Tam, O. K., \& Tan, M. (2007). Ownership, governance and firm performance in Malaysia. Corporate Governance: An International Review, 15(2), 209-222. 
Uzun, H., Szewczyk, S., \& Varma, R. (2004). Board composition and corporate fraud. Financial Analyst Journal, 60(3), 33-43. http://dx.doi.org/10.2469/faj.v60.n3.2619

Vafeas, N. (1999). Board meeting frequency and firm performance. Journal of Financial Economics, 53(1), 113-142. http://dx.doi.org/10.1016/S0304-405X(99)00018-5

Vicente-Villardon, J. L. (2008). Multibiplot: Multivariate analysis using Biplots. Spain: Department of Statistics, Universidad de Salamanca.

Weir, C., \& Laing, D. (1999). Governance structures, size and corporate performance in UK firms. Management Decision, 37(5), 457-464. http://dx.doi.org/10.1108/00251749910274234

Wood, M., \& Patrick, T. (2003). Jumping on the bandwagon: Outside representation in corporate governance. The Journal of Business and Economic Studies, 9(2), 48-53.

\section{Copyrights}

Copyright for this article is retained by the author(s), with first publication rights granted to the journal.

This is an open-access article distributed under the terms and conditions of the Creative Commons Attribution license (http://creativecommons.org/licenses/by/3.0/). 